JOURNAL OF LIFE ECONOMICS

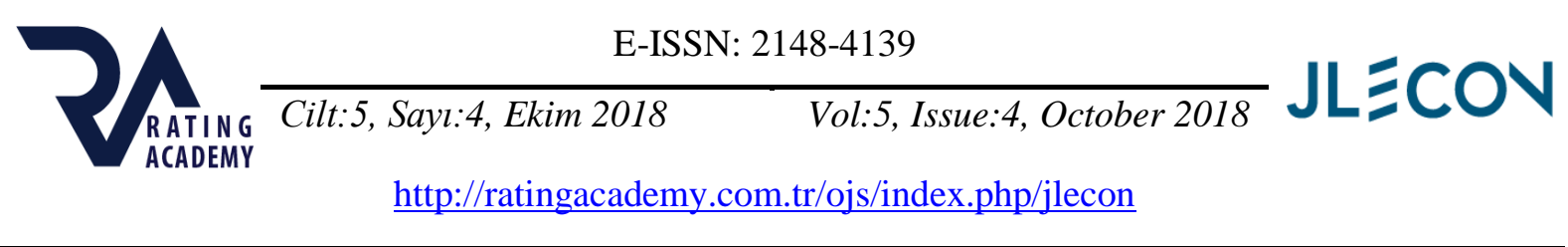

\title{
THE DEMAND FOR ELECTRICITY CONSUMPTION IN TURKEY
}

\author{
Res. Asst. Başak SEZGIN \\ Anadolu University, \\ Faculty of Economics and Administrative Sciences, \\ Department of Economics, Eskişehir/TURKEY \\ E-mail: basaksezgin@anadolu.edu.tr \\ Assoc. Prof. Dr. Selim YILDIRIM \\ Anadolu University, \\ Faculty of Economics and Administrative Sciences, \\ Department of Economics, Eskişehir/TURKEY \\ E-mail:selimy@anadolu.edu.tr
}

\begin{tabular}{l|l}
\hline ARTICLE INFO & \multicolumn{1}{c}{ ABSTRACT } \\
\hline $\begin{array}{l}\text { Article History: } \\
\text { Received: } 26 \text { September } 2018 \\
\text { Accepted: } 22 \text { October 2018 }\end{array}$ & $\begin{array}{l}\text { This study aimed to determine the effects of socio-economic variables on } \\
\text { poverty. For this purpose; education, working population ratio, the } \\
\text { national income according to purchasing power parity, the inflation rate } \\
\text { and the net wage effect on poverty for selected eight EU countries between } \\
\text { 2006-2015 were analyzed using the fixed effect model, the random effects } \\
\text { model, the pooled regression model and the generalized method of } \\
\text { moments of the panel data methods. It is reached that while the national } \\
\text { income has poverty reduction effect in all models according to purchasing } \\
\text { Modified } \text { OLS (FMOLS), Turkey } \\
\text { power parity, education has poverty reduction effect in other models except } \\
\text { the fixed effects model. Inflation and working population ratio do not seem } \\
\text { to have an impact on poverty. }\end{array}$ \\
\hline DOI: 10.15637/jlecon.260
\end{tabular}

\section{INTRODUCTION}

Electricity has been in our life for almost more than a century. One of the most long going topic of the recent years is the level of electricity consumption and how to supply it. Countries are bound to electricity whether it is to elevate the quality of life or for development of industry or lightening and transportation. What makes electricity unique to other commodities is, it has to be consumed when it is produced due to the fact electricity cannot be stored. Therefore, calculating the production of electricity should be done rigorously which show the importance of modelling electricity consumption and the determinants of electricity consumption.

This study is primarily focused on determinants of electricity consumption for Turkey between the years 1960 and 2016. The objective for the study was to suggest the right model for the electricity consumption and find out the relationship between income, industrialization, 
financial development, education levels, carbon emission, price of electricity, urbanization, and trade openness.

This paper firstly gives a general description of energy, its sources, and electricity as well as the historical progress of energy and electricity. Secondly, the paper assesses the existing literature on electricity consumption by reviewing electricity consumption studies around the world then studies that examined in Turkey. Thirdly, the work provides empirical time series evidence for Turkey applying the Phillips and Hansen's (1990) Fully Modified OLS (FMOLS) models for estimations.

\section{ENERGY SECTOR IN TURKEY}

\subsection{Historical progress of the energy sector in Turkey}

Until the end of the 16th century the Ottoman Empire was technology same as the European countries. Although at the time of the industrial revolution the Ottoman Empire could not keep up with the advancing technology. The capital city of the Ottoman Empire did not have any sort of lighting and the first time the streets were lighted was after the Rescript of Gülhane in 1839 when the people were asked to put oil lamps in front of their houses and shops. While poorer families used oil based products, only the wealthier families used wax in their houses and by the year 1860 wealthier families started using petroleum for lighting. In the year 1846 it was written in a government notice that it was necessary for the public good and that it was the command of the sultan to light up the streets. It was made mandatory to put oil lamps in front of people's houses and shop owner's shops. The efficiency of the coal gas compared to other sources, coal gas facilities widespread in the 19th century and almost all lighting in houses and street were sourced by coal gas at that time. In 1855, Sultan Abdulmecit wanted the newly built Dolmabahçe Palace to be lit like European palaces so in order to achieve that the first gas station built in Istanbul, the Dolmabahçe Gas Station was built. The second gas station to be built was the Kuzguncuk Gas Station and it was built to light the Beylerbeyi Palace. The excess gas was used for the lighting of the streets of Üskudar. The gas station made for social purposes in Istanbul was at 1880, the Yedikule Gas station. These stations lit the street lamps of Istanbul with coal gas light until 1940 (Özdemir, 2012: 31). The industrialization initiatives of the Ottoman Empire were mainly based on improving the military or government. In the years 1830 to 1840 the machines that were deported from Europe were to meet the demand of the navy and the palace. While foreigners and non-Muslims in the empire were pioneers of banking and transporting, the Turkish people were mostly farmers, civil servants, soldiers and tradesmen. By the year 1876, the Ottoman Empire was in debt to many European countries who formed an administration to collect their debt named "Duyun-u Umumiye Administration". This administration shifted the major government income source to pay the owned debt. In the beginning of the 20th century, the Ottoman Empire's continued wars had a negative impact on the country's budget. In the first years of the wars, basic needs like bread, wheat, salt, sugar, and gas oil were scarce, although at the time in the Empire the main economic activity was farming, and the industry was not yet developed. Industrialization gained importance only after 1908, after when the second constitutional monarchy was declared. Investments for industrialization were based on national capital but foreign capital dominated the industry and because trading was handled by Greek, Jewish, Levantine, and Armenian living in the Empire instead of the Turks it was a challenge to transition to national capital dominance. Before electricity the Ottoman Empire based its energy solely on physical human strength, the main economic activity was mostly agriculture, farming. Industrialization was an economic area that was intended to improve in a national way, but the wars prevented it. National industry and national trade were especially necessary after the minority groups who were dealing with industry and trading separated from the Ottoman Empire between the years 1917 - 1924. 
Following the year 1915 and the First World War, any kind of case of foreign trade did not exist and in the year 1922 the Ottoman Empire collapsed. The Ottoman Empire was an open market so transportation, banking, trade dealing was profitable however operating an industry in the Ottoman lands was costly because of the lack of infrastructure, energy, and qualified labour forces. The energy used in the limited amount of industries that were built were mostly based on manpower, stream power and internal-combustion engine which used oil. Electric motors were only used in factories that were in Istanbul. The first application of electricity can be considered the use of telegraph in 1855. The line was drawn between Istanbul and Edirne and it connected to the Austrian network via Rousseau. In a very short time after also connecting with Europe, telegraph lines were drawn all over the country. When the first telegraph line was drawn in the Ottoman it had only been 18 years since the telegraph lines were drawn in England. In a very short time the Ottoman Empire accepted the telegraph, this was because it required a low cost and the benefit that it brought weighted its cost. The widespread of the telegraph increase communication and therefore diplomacy in the land. Although the telegraph had a widespread acceptance in the empire; the telephone which was spreading in Europe in from 1877, was establish after the constitutional monarchy was declared (Özdemir, 2012: 37-41).

While electricity was popularizing in America the Ottoman Empire first met electricity in the beginning of the 20th century. The first production of electric was in the 1902 in the town of Tarsus. A water mill located upon the river of Berdan near Tarsus was transformed in to a power plant using a driving belt strapped to the shaft of the mill turning a dynamo that produced $2 \mathrm{~kW}$ of electricity. This small power plant was later turn to a hydroelectric plant and produced $60 \mathrm{~kW}$ electricity that supplied the town with electricity.

The capital Istanbul's lighting demand could not be met with gas lighting alone, so The Dolmabahçe Gasworks was closed in order to replace gas lighting with electricity to light the city. After the law regulating concession that were granted to foreign companies was issued in 1910 the government prepared a specification to supply electricity to Istanbul and opened an international tender in accordance with this specification. The Austrian-Hungarian company Ganz which was known for electric tram manufacturer, was permitted with the concession to supply electricity to Istanbul under the new regulation law. The Ganz company combined their power with a couple of other companies established "The Ottoman Electricity Incorporation". This incorporation later built a coal-fired thermal power plant in Silahtarağa that would be the electric power plant in the Ottoman Empire to supply a city. The Silahtarağa Electric Power Plant was the first ever power plant to apply the build-operate-transfer model.

The electricity produced in Silahtarağa was firstly commercial purpose and was used to run trams in İstanbul. It started the trend for concession companies which was later used for tram operations in İzmir and the general electrification of Istanbul in 1914. During the constitutional monarchy only, Istanbul was provided with electricity. The main source of energy for The Silahtarağa Electric Power Plant was provided from coal which was mostly obtained from Zonguldak. The many of the ships that carried coal from Zonguldak to Istanbul were sank during the first world war, leaving the capital Istanbul and the navy in need of coal supply. With an ongoing war the supply of coal could not be met by importing it from sea and rail roads. This leads to a scarcity in coal and steam coal, and for the production to drastically fall. The "Istanbul Electric Company" which opened in 1914 could not provide electricity to the capital during the First World War due to the scarcity of coal. In the June of 1923 the company's name was changed to the "Turkish Incorporated Electricity Company". (Özdemir, 2012: 55-58). 


\subsection{During the Republic of Turkey}

The electricity sector in Turkey was held by foreign companies of Germany, Belgium, Italy and Hungary at the time of 1914. The relationship between European countries had worsen after the First World War which lead countries that depend on European countries to decrease their foreign market which also resulted in their domestic industries to develop. The Turkish Grand National Assembly accepted a law in 1921 that encouraged industrialization and private capitals in sectors that lead to revitalizing some industries. The law permitted taxes and fees including giving free land to business owners for construction. The permission given for importing raw material and machinery without paying customs did not result favourably. The ongoing wars of the Independent War left Turkey with a collapsed economy. Industries and production had stopped, agriculture was lagging new technologies as well as the number of working men had decreased, foreign debts and unemployment had increased, and transportation could not be provided. At the time of the end of the war most businesses were run by foreign businesses which lead to them abandoning the country pushing the Turkish people to enter a self-sufficiency process. The 1921 Constitution had adopted a principle of national will that provides legitimacy to the War of Independence. After the halt caused by the independence war, electricity extended quickly to the whole country. In 1923 Adapazar1; In 1925, İzmir, Adana, İnebolu, Artvin, Trabzon, Akşehir, Mersin; 1926 in Sivas, Aksaray, Konya, Ayvalık, Bursa, Malatya, Izmir, Kütahya; In 1928, Nazilli, Kırkağaç, Antalya, Afyon, Akşehir, Kırklareli, Samsun, Çorlu, Giresun, Eskişehir, Yozgat; 1929 in Bandirma, Biga, Milas, Ordu, Bafra; In 1930 Balikesir, Kastamonu, Tekirdağ, Urfa was electrified. At the time of the 10th year of the republic the number of provinces and districts that had electricity was 105. In July 23th, 1923 with the war of Independence ending, and after the foundation of the Turkish Republic, the Government of the Republic of Turkey issued a law establishing the legal status of the foreign companies in the Turkey. The contracts with the person or companies that received the electricity concession continued the existing contracts and the applications continued as they were. The law stated that any joint-stock company that was establish before March 16th, 1923 were to foresee that in order to ensure their compliance with the present Constitution, the Trade Vicant shall make the necessary arrangements, since almost all of the joint stock companies had laws according to the laws of the former Ottoman Government that are contrary to the Constitutional Law. The "İzmir Economics Congress" which was held between February 17 and March 4, 1923, was attended by the National Trade Union of Turkey and the subject matter was progress to be made in the fields of agriculture, industry, banking and transportation. The decisions taken from the İzmir Economics Congress was in the lines of adopting liberalism although it had been approved that the state should support the private enterprise and invest in the private sector in cases it was not sufficient or profitable. Mustafa Kemal Pasha even stated in the congress that foreign capital could be an option as long as they are not in conflict with the interests of the state. Straight after the congress the Agricultural Bank of the Republic of Turkey (Ziraat Bank) was reorganized, and in 1927, the "Industrial Promotion Law" was issued with the aim of promoting and protecting industrial establishments. With this law, state subsidies such as cheap government subsidies, various tax exemptions, transportation and transportation incentives and capital incentives were given to the domestic industry sector. When the republic was form in 1923 the installed power capacity was $32.8 \mathrm{MW}$ and only Istanbul, Adapazari and Tarsus, in today's borders of the Republic, were electrified cities. Only $94 \%$ of the population had access to electricity therefore the electricity consumption per person per year is about $3 \mathrm{kWh}$. The works on electrification were accelerated to provide electricity to all of the cities and new industrial facility that were to be established.

The larger cities were planned on lighted with electricity while smaller cities were to be lighted with gas at the beginning. The usage of electricity manufacturing processes started for 
the factories and cement factories, bakeries, weaving factories, ice making plants, fish processing factories, cigarette factories and small workshops, woollen fabric factories and in the following years, automotive sector factories started using electricity in their manufacturing process. In addition, Osram, Philips, Luma, Astra, Tungsram Kripton brands have begun producing electric wires and light bulbs to trade. Also, auxiliary jobs such as electric repair, electrical material merchandising, etc., which can cope with electrical problems, emerged. The electricity generation and distribution of the Anatolian side of Istanbul which would be around Kadiköy and Üsküdar, was given to Kadıköy Gas Company by the government in 1924. In 1926 the company bought Istanbul Gas Company and formed the company named abbreviated as 'SATGAZEL' (Istanbul Gas and Electricity and Enterprises). The importance of gas decreased as the prevalence of electricity increased so the company intended to enlarge the area of which it provided electricity to. In the 1930s it continued the network expansion by installing underwater cables from Kartal to Büyükada and started supplying electricity to the Prince Islands. In 1932, the network was extended to Heybeliada. The first power plant to be establish in Ankara was a direct current dynamo with a power of $35 \mathrm{kWh}$ which was rotated by locomotive at 50 horsepower in Bendderesi, in 1925. The second power plant which was a diesel generator that provided Ankara with electricity, was established in accordance to the policy of privileged partnership in electricity, by the German MAN and AEG companies in 1925. During the time of the Ottoman Empire the concession would be given to the most suitable bidder was selected from among the persons or companies this biding system was turned into auction by underbidding and sealed bid method during the period of the Turkish Republic. The Great Depression of 1929, affected Turkey in the depreciation of the Turkish Lira, increase in imports and decrease in exports, the start of indigenous property incentive initiatives, and deficit in foreign trade. The inflationary environment, excessively raised the electricity prices and the increase in electricity production did not reduce the electricity prices. After the 1929 economic depression and from 1930 onwards in Turkey as well as in the world statist policy had gained importance. Since the effects of the 1929 crisis were not possible to stabilize for the private enterprise in liberal means, state intervention had become more effective in underdeveloped countries like Turkey, where the private enterprise was not strong.

By 1930, the installed power reached $78 \mathrm{MW}$, and the gross electricity generation was 106.3 GWh while the net consumption reached $96.7 \mathrm{GWh}$. The population in 1923 was 12.360.000 when we look at 1930 it increased to 14.448 .000 . The gross production per capita had increased from $3.6 \mathrm{kWh}$ to $7.4 \mathrm{kWh}$, while consumption per capita had increased from 3.3 $\mathrm{kWh}$ to $6.7 \mathrm{kWh}$. Also, thermal and hydroelectric power was given attention to and in 1930 thermal power capacity increased to $104.4 \mathrm{GWh}$ while hydroelectric capacity increased to 1.9 GWh. The electricity produced in Turkey was produced $94 \%$ by foreign companies, $4 \%$ by municipalities and $2 \%$ by people. Electricity production in Turkey had been in the hands of foreign companies operated by small local power plants and their separate local distribution networks. The electricity which was initially only used for lighting was used in the industry after 1930. Between the years 1930-1939, statist and protectionist politics lead to the import substitute industrialization model for basic consumption and intermediate goods production. The great depression lead to Turkey implementing a closed economy and a state-organized national industrialization. Between the years 1938 and 1944, the electricity generating companies with foreign capital privileged partnerships in the cities of Istanbul, Ankara, Adana, Bursa, Mersin, Balikesir, Gaziantep, Tekirdag, Edirne, İzmir, Antalya, Trabzon and Malatya were bought by the government with the enacted laws in order to nationalize the electricity sector. Only Kayseri and Civari Electricity Trading Co. was not nationalized (Demirel, 2016, p. 67, 100). Also, in 1930 it was permitted to the municipalities by the law on municipalities, to produce electricity and with the "First Industrial Plan" in 1933, the government was decided to be responsible of generating electricity. Around the year 1935, the Etibank which was 
establish with the aim to finance mines and raw material used by the industry and power plants operated by the government, the Mineral Research and Exploration which was founded to systematically search and operate the mines with the necessary geology and mining methods, Electrical Works Research Administration which was establish to study the hydropower potential of the country and to prepare an electrification plan for the country by identifying the most suitable underground and water resources, became active. The year 1948 marks an important milestone; the Çatalağzı Thermal Power Plant belonging to Etibank, which was started in 1941 was finished and for the first time a regional power plant had been commissioned. The Çatalağzı Thermal Power Plant was built in the town of Çatalağzı in Zonguldak, a city known for mining coal. In 1952 a transmission line of $154 \mathrm{kV}$ was connected to the thermal power plant to supplement the electricity transmitted to İstanbul. From 1914 until 1952 Silahtarağa Power Plant was the only power plant that met the electricity need of İstanbul, with the connection of Çatalağzı the city of İstanbul was supplied by two power plants. In the 1950 's a mixed economic policy was followed leading to electricity being produced by not only government enterprises but by private enterprises with build-operate models as well. The 1950's was also the years where Turkey had transited to an interconnected system in electricity transmission, meaning every single power plant large scale or small scale would be connected so a power cut would have a minimum effect. Turkey's electricity capacity had reached 789.5 million $\mathrm{kWh}$ and electricity production per person per year had reached $33 \mathrm{~kW}$ in these years.

In the years 1952 and 1956, four private companies with domestic capital were allowed to be established, these were Çukurova Electric Co. which would operate in Adana and İçel regions, Kepez Electric Co. which would operate in Antalya region, Northwest Anatolia Electrification Co., which would operate in the Northwest Anatolia Region, Turkish Aegean Electric Corporation which would operate in the Aegean region. Unfortunately, these joint stock companies were not successful therefore they were liquidated. Hydroelectric power plants were decided to be built, in 1953 an establishment called State Hydraulic Works (DSI) was found which aimed to build hydroelectric power plants. In 1956, the Sarıyar Dam HEPP was in service with power of $160 \mathrm{MW}$, and in 1959, Hirfanlı Dam HEPP in service with power of $128 \mathrm{MW}$. The private and public sector's investments totalled at $1272.4 \mathrm{MW}$, electricity production amounted 2815.1 million $\mathrm{kWh}$ and annual electricity production amounted to $87 \mathrm{~kW}$ per capita around the 1960's. In addition, the 5-year development plans have been introduced to ensure the integrity of the units and administration in the other ministries in the energy sector. The Energy and Natural Resources Ministry was found in 1963 to evaluate energy resources and natural resources of the country. The increase amount of production, transmission and distribution of electricity, TEK (Turkish Electricity Administration) was established with the law no. 1312 in 1970. This law also transferred Etibank, DSİ, Iller Bank and municipal power plants to TEK meaning the electricity generation was transferred to TEK while the transmission and distribution lines that belonged to the municipalities where left. In the 1970s, Turkey's installed power was 8623 million kWh with an electricity potential of $2234.9 \mathrm{MW}$ and the electric production per capita per year reached $207 \mathrm{~kW}$. The 1970's world crisis lead the construction of the hydroelectric plants to gain importance and the construction of them gaining speed due to the fact thermal power plants energy sources were imported to Turkey. The Gökçekaya Dam HEPP with 278 MW power was built in 1972 and the Keban Dam Hes with 1330 MW power in 1975. The 1970's saw electricity interruptions and electrical raw material troubles while investments in hydroelectric power plants increased. In the 1980's Turkey had an electric potential of 5118.7 MW and installed power of 23275.4 million $\mathrm{kWh}$ as well as the electricity generation per person per year reaching $459 \mathrm{KW}$. Turkey's economic liberalization policies which started in the 1980s, made changes in the electricity sector. In 1982 problems between the transmission and distribution lines occurred due to municipalities and TEK disagreeing. This resulted in all the electricity facilities being transferred to TEK in order to 
provide unity. Then the electricity production and selling the produced electricity to TEK was given to private sector without any time constrains. In the year 1984 the principle of TEK being the only electricity producer was abandoned and a law that allow the generation, transmission and distribution of electricity by institutions outside the Turkish Electricity Authority (TEK) was invoked. With the same law build-operate-transfer and the transfer of operating rights were regulated which pave the way for private sector companies to participate in electricity production, transmission and distribution. But the first major project was held in 1996 due to the fact that there was lack of regulation on many subjects. At the beginning of the 1990s, Turkey produced 57543 million $\mathrm{kWh}$ of electric power and had an installed capacity of 16315.1 MW while electricity per person per year reached $855 \mathrm{~kW}$. The $1990 \mathrm{~s}$ were primarily concerned with privatization and the preparation of legal infrastructure for investments in private sector to participate in the energy sector. In the year 1993 TEK was reconstructed as a governmentowned corporation and was divided as Turkey Electricity Generation and Transmission Company and Turkish Electricity Distribution Company with the decision of the Council of Ministers. In 1994, the Law on Privatization of TEK had entered into force, but the law was abolished by the Constitutional Court. Also, the same year, private and foreign capital companies were allowed to take part in the production, transmission and distribution of electricity subjected to the provisions of the private law and in the framework of the BuildOperate-Transfer model. At the beginning of the 2000's, Turkey's electricity production had increased to 124921.6 million $\mathrm{kWh}$, and the installed capacity was $27264.1 \mathrm{MW}$ while the electricity generation per capita had reached $1457 \mathrm{~kW}$. While both the 1990's and 2000's continued developments in the electricity sector, in the 2000's the restructuring and the renewal of the legislation of the process of the electricity sector that came from the past was focused on. In the year 2001 the one of the most important advancement in electricity sector was the establishment of the Electricity Market Regulatory Authority which name was later change to the Energy Market Regulatory Authority. The Electricity Market Regulatory Authority was established with the aim to provide consumers with sufficient, high quality, continuous, low cost and environmentally friendly electricity; establish a financially strong, stable and transparent electricity energy market that can operate according to the provisions of private law in a competitive environment; and provide independent regulation and supervision in the market. Also, in 2001, TEAŞ (State Electricity Generation and Transmission Corporation) had been divided into three legal entities for each activity. These government-owned corporation were Electricity Generation Inc. (EÜAŞ), Turkish Electricity Transmission Co. Inc. (TEİAŞ), and Turkish Electricity Contracting and Trading Co. Inc. (TETAŞ). In the year 2004, by the decision of the Higher Planning Council, the electricity distribution network within TEDAŞ had been allocated into twenty-one regions and it has been decided that the areas besides the Kayseri region should be included in the facilities that are to be privatized. In the 2010 the numbers for Turkey's electricity production have been revealed by TEİAŞ as 209 billion 389.5 million $\mathrm{kWh}$ in electricity consumption, 181.6 GWh in total electricity generation, a total of 882.5 GWh of electricity purchased from countries like Iran, Georgia and Azerbaijan within the framework of various agreements. Also, production of electricity by the Electricity Generation Corporation (EÜAŞ) thermal power plants decreased by 10.7 percent to 37 thousand 901.5 Gigawatts (GWh) compared to the previous year, while the production in hydraulic power plants increased by 45.4 percent to 41 thousand $210.4 \mathrm{GWh}$. The production of electricity for the partnerships with EÜAŞ decreased by 12.9 percent (16 thousand $254.7 \mathrm{GWh}$ ), for the power plants with transfer of operational rights it decreased by 1.1 percent (4 thousand $323.6 \mathrm{GWh}$ ), for the auto producers it decreased by 12.5 percent ( 11 thousand $807.8 \mathrm{GWh}$ ) for build-operatetransfer it decreased 2.2 percent. $(13,555.8 \mathrm{GWh})$ compared to the previous year. Thus, after several years, the share of natural gas in production decreased, while the share of hydropower increased considerably. (Yavuz, Gürkan, \& Şimşek, pp. 2-6) 


\subsection{Energy today in Turkey}

The energy consumption in Turkey according to data from August 2017 is percentagewise $43 \%$ natural gas, $30 \%$ electricity and $20 \%$ motor consumption. The total electricity consumption was 28,105,116 MWh as of August, the production sources for electricity was listed as natural gas with the largest share of $38 \%$, followed by imported coal with $18 \%$, hydroelectric power plant (from dams) with $15 \%$, lignite with $13 \%$, and wind with $8 \%$. (Karakış, 2017). In Turkey, lignite can be evaluated in national reserves and production quantities at medium level and coal at low level according to world standards. Nearly $3.2 \%$ of the world total of lignite / sub bituminous coal reserves can be found in Turkey. The most important coal reserves in Turkey are located in and around Zonguldak which has a total coal reserve of 1.30 billion tons, while the apparent reserve is 506 million tons while $46 \%$ of Turkey's lignite reserves are located in the Afşin-Elbistan basin. However, since most of the lignite found in Turkey have a low thermal value, its preferred use is in thermal power plants. By 2005 , in order to meet the increasing energy demand with the industrialization and population increase and the targets of giving importance to domestic resources in energy production and reducing external dependency; the discovery of new coal fields and the development of known fields have been accelerated. Approximately $72 \%$ of the world's oil and natural gas reserves are located vicinity of Turkey which includes energy-rich Caspian, Central Asia, and Middle East countries. The oldest pipeline that is located in Turkey is the Iraq-Turkey Crude Oil Pipeline that transports Kirkuk's oil in northern Iraq to the west. Another pipeline carrying oil is the Baku-Tbilisi-Ceyhan (BTC) Crude Oil Pipeline that was opened in 2006 and had reached the carrying capacity of 1.2 million barrels per day in 2009. In increase in the importance of shale gas lead to the search of shale gas in Turkey which resulted in wells being opened in South-eastern Anatolia and Trakya Regions and studies on reserve determination are being continued. Natural gases are mainly used for heating and as a whole the supply-demand of natural gas annually is balanced however in the winter months when the demand for natural gas increases there can be imbalances in the supply-demand due to maximum level of daily consumption, temperature being below the seasonal norms, and obstacles in the route countries. The supply sources and routes of natural gases are diversified in order to obtain a supplydemand balance. The first nuclear power plant to be open in Turkey will be Akkuyu Nuclear Power Plant which is planned to start operating in 2023. The second nuclear power plant to be establish in Turkey is Sinop Nuclear Power Plant project which conducted as an intergovernmental agreement on nuclear power plant construction and cooperation with Japan. Nuclear power plants are needed in order to meet the increasing electricity demand and to reduce the risks arising from import dependency. The Hydroelectric production of Turkey was measured as 67.3 billion $\mathrm{kWh}$ in 2016. Wind power plant establishment terms in Turkey are considered to be areas that are 50 meters above ground level and have a wind speed over 7,5 $\mathrm{m} / \mathrm{s}$ where $5 \mathrm{MW}$ per square kilometre electricity can be generated. The wind energy potential in Turkey is identified as 48,000 MW as well as the total area corresponding to the potential is $1.30 \%$ of Turkey's surface. Turkey has a high solar energy potential because of its geographical position. The Solar Energy Potential Atlas of Turkey (GEPA), identified the annual sunshine time to be 2,737 hours (total daily 7.5 hours), and the annual total incoming solar energy as $1,527 \mathrm{kWh} / \mathrm{m}^{2}$.yll (daily total of $4.2 \mathrm{kWh} / \mathrm{m}^{2}$ ). The geothermal potential of Turkey is theoretically calculated a 31,500 MWt and $78 \%$ of the potential areas are located in Western Anatolia, 9\% in Central Anatolia, 7\% in Marmara Region, 5\% in Eastern Anatolia and 1\%. The majority of the geothermal resources are in the range of low and medium temperature which is suitable for direct applications (heating, thermal tourism, mineral waters etc.) while about $10 \%$ is suited for indirect applications such as electric energy production. The first electricity production in geothermal energy applications in Turkey was started in 1975 named the Kızıldere Power Plant which was built in Sarayköy district of Denizli province with a power of 
0.5 MWe. Turkey's total geothermal heat capacity which is the amount of visible heat, has reached 15,500 MWt. Turkey's biomass waste potential is about 8.6 million tons in oil equivalent (toe), the amount of biogas produced can be estimated to be 1.5 to 2 MTEP.

Turkey's main energy source for generating electricity by 2017 can be listed as: $34 \%$ from natural gas, $31 \%$ from coal, $24 \%$ from hydraulic power, $6 \%$ from wind, $2 \%$ from geothermal energy and 3\% from other sources. Natural gas with a percentage of 34 is the main energy source in Turkey followed by coal and hydro energy sources.

Turkey's 278.4 billion kWh electric energy consumption in 2016 increased by $4.7 \%$ to 167.1 billion $\mathrm{kWh}$ in 2017 and electricity production increased by $6.7 \%$ compared to the end of July of 2016, to 167.3 billion kWh by the end of July 2017. As of the end of July 2017, the total installed capacity of electricity has increased by 2,049 MW and the installed power reached 80,546 MW by the end of July 2017. According to the projections, electricity consumption is expected to reach $385 \mathrm{TWh}$ in 2023 with an average annual increase of $4.8 \%$. As of the end of July 2017, EÜAŞ has a $25.1 \%$ share, free production companies have a $61.5 \%$ share, build-operate power plants have a $7.6 \%$ share, build-operate-transfer stations have a $1.7 \%$ share, power plants with transferred the operating rights have a $2 \%$ share and unlicensed plants have a $2 \%$ share in the installed power in Turkey. The number of electricity generation power plants in Turkey including unlicensed power plants, have increased to 3.098 and of the existing power plants, 613 are hydroelectric, 40 are coal sourced, 186 are wind powered, 33 are geothermal sourced, 288 are natural gas sourced, 1,773 are solar powered and 165 use other sources. The acceleration in the electricity consumption prompts the works on strengthening the electricity infrastructure to continue uninterruptedly. In addition to the strengthening efforts carried out nationally, a significant ground has been gained to strengthen Turkey's international electrical connections and increase capacity. In this context, a Long-Term Agreement was signed between TEİAŞ (Turkish Electricity Transmission Corporation) and ENTSO-E (European Network of Transmission System Operators for Electricity) on April 15, 2015 and the Turkey's electricity system was permanently connected to the European electricity system.

\section{REVIEW OF THE LITERATURE}

Empirical studies of the electricity demand have received considerable attention in both developed countries and developing countries. There are several empirical studies that have examined the determinants of the demand for electricity in a number of countries.

The review of existing literature in the field of economics of the electricity consumption shows that studies in this area mainly focus on either testing whether electricity consumption plays a positive role in stimulating economic growth or determining the electricity consumption. There are many cross-country and single country empirical studies that support the positive association between electricity consumption and economic growth. Taylor (1975) surveyed the demand for electricity. In his work, he critiques economic literature on determinants of electricity. He points out that determinants of electricity consumption are a function of the level of income, the price of the goods and the prices of the other goods.

$$
\mathrm{q}=\mathrm{f}\left(\mathrm{x}, \mathrm{p} \_1, \mathrm{p} \_2, \ldots \mathrm{p} \_\mathrm{x}\right)
$$

Where q denotes the quantity consumed of electricity, x refers to income and p1, p2., .... px represent the price of the goods (Taylor, 1975: 79).

Taylor has also analyses and critiques the short run and long run demand for electricity. In demand analysis, residential consumption, industrial consumption, commercial consumption critically reviewed respectively. (Taylor, 1975: 80-90). 
Taylor has also provides an evaluation and critique of studies concerning electricity demand. He summarised and described studies as follows: The price elasticity of demand for electricity, for residential, commercial and industrial is much larger in the long run than in the short run. Income elasticity of demand is also having same pattern. In the long run, price elasticity of demand is indicated to be elastic. Income elasticity in the long run showed mixed results. (Taylor 1975: 108)

Tiwari (2000) paper has analysed determinants of residential electricity demand in Bombay. He used 6358 households survey of Bombay Metropolitan Regional Development Authority in the years 1987 and 1988. The estimated elasticities for income is positive and 0,34 and elasticities for price $-0,70$. The main conclusion of this study is that residential electricity consumption is inelastic with respect to both income and price (Tiwari, 2000).

Nasr, Badr and Dibeh (2000) estimated electricity consumption in post war Lebanon for the period of 1993-1997. They found that the impact of the gross domestic product proxied by total imports is a significant determinant of energy consumption, whereas degree days have a negative correlation (Nasr, Badr and Dibeh, 2000).

Al-Faris, Abdul Razak F. (2002) used cointegration techniques to estimates the effects of economic variables on electricity demand in the Gulf Cooperation Council countries for the time period of 1970-1997. Their finding showed that elasticities of price and income are notoriously small which may indicate that the majority of people in these countries consider electricity as a necessity. Cross-price effects (of competing fuels) are small which may support the argument that the scope of energy switching, especially in residential sector, is still limited (Al-Faris, Abdul Razak F. 2002: 121).

Mohamed and Bodger (2005), study on forecasting electricity consumption in New Zealand. Their study uses gross domestic product, average price of electricity and population of New Zealand during the period 1965-1999.

Ekpo, Chuku, and Effiong (2011) paper titled the dynamics of electricity demand and consumption in Nigeria. Between 1970 and 2008, a boundary testing approach was used in Nigeria to empirically investigate electricity demand and consumption dynamics. It also provides background analysis of electricity demand and consumption trends in Nigeria. Findings of the study show that long term electricity consumption is positively affected by the income, population and industrial sector production. It has come to conclude that the electricity price is insignificant because it is determined by the government. The income elasticity indicates that electricity is normal good which increases with income, while magnitude of the population parameter suggest that population drives the consumption of electricity more than other variables in the Nigerian case (Ekpo, Chuku, and Effiong, 2011).

Xia and $\mathrm{Hu},(2012)$ analyses the determinants of the intensity of electricity consumption in China using data from Chinese cities at the provincial level in 2009. Their paper the most elaborate representation of electricity consumption intensity in China. The model used include so many variables as output concentration, decease rate of energy intensity of industry, population concentration, industrial concentration, fiscal concentration, share of industrial employment, share of industrial output, decease rate of electricity consumption intensity, investment concentration, share of industrial electricity consumption, decease rate of energy intensity, urbanization degree of the province, share of non-agricultural population, urbanization degree of the city, average retail price of electricity, annual average temperature and ensured reserves of iron ore.

Bedir, Hasselaar and Itard (2013) study aimed to identify the impact of the use of lighting and other electrical appliances in Dutch houses on electricity consumption and 
determine what constitutes the determinants. The data were collected by questionnaire in 323 houses in the Netherlands. Estimates were made using three regression models. This research proved that duration of electrical appliance uses, and household characteristics are important predictors in models of electricity consumption. The results also show that hourly data on presence at home or in rooms do not help to explain electricity consumption with regression analysis. No correlation was found between electricity consumption and mechanical ventilation systems. Household size cause an increase on electricity consumption increases. They found in their first model that total duration of appliance use alone explained $37 \%$ of the variance in electricity consumption (Bedir, Hasselaar and Itard, 2013).

Krishnamurthy and Kriström, (2013) study is different from other studies that their objective of study is an estimation of price and income elasticity selected eleven OECD countries. They used survey data, including countries Australia, Canada, Chile, France, Israel, Korea, Japan, the Netherlands, Spain, Sweden and Switzerland. They find strong price responsiveness, with elasticities for most countries in the sample. They find evidence for nonprice related factors to significantly affect energy demand. Price elasticity are in contrast with many existing studies indicating more policy space for demand reduction than previously thought. All variables, are negatively associated with demand, except for price and home ownership. Age is positively associated and is significant while education and home ownership are insignificant (Krishnamurthy and Kriström, 2013).

Huang (2015) develops an empirical model of determinants of household electricity consumption in Taiwan and employs quantile regression. The cross-sectional Family Income and Expenditure Survey conducted once a year by the Taiwan government. In this study the data used during the period of 1981 to 2011. The research examines how the effects of socioeconomic and demographic household characteristics on electricity consumption change over time. They employ quantile regressions and claim that if the residual series is non-normal quantile regressions can be more efficient than the OLS method. The findings of this study indicate that the impacts of electricity consumption on demographic, socioeconomic, and household dwelling characteristics may differ across quantiles and change over time and also household income and household size were significant in all quantiles for each year (Huang, 2015).

Fakih and Marrouch (2015) has investigated the electricity consumption, employment and growth nexus for Lebanon. The method used in the paper is Granger causality. The causal relationship between electricity consumption and growth in Lebanon is examined for the period 1980-2011. The main finding of this study is that economic growth in Lebanon is more responsive to the employment level than to electricity consumption (Fakih and Marrouch, 2015).

Alawin, et al., (2016) paper analysed the energy sector in Jordan for the period 19852006. The study showed that the growth of the real GDP and population caused higher demand for electricity. On the hand, the energy price index and efficiency improvement in the manufacturing sector were negatively related to the demand. The study used real GDP growth rate, population growth, the domestic energy price index and improvement in production efficiency in the manufacturing sector with an Auto Regressive Distribution Lags (ARDL) model to determine the components of the electricity demand in Jordan. Consistently the results have shown the real GDP and population growth has a positive and significant effect on the growth in electricity also the manufacturing sector performance improvements decrease the electricity demand. The findings also point out an unusual effect of electricity consumption reducing if the level of domestic inflation rises (Alawin, et al., 2016). 
Kwakwa, (2017) examined a long-run analysis of determinants of electricity consumption in Egypt. This paper is case study of Egypt and main motivation of our thesis. Sample period of the study is between 1971 and 2012. He claims that determinants of electricity consumption in Egypt are electricity consumption, price, per capita income, urbanisation, financial development, carbon emission, trade and education. The findings of the paper are that urbanisation, education, financial development, income and trade positively affect electricity consumption. On the other hand, industrialisation had negative effect on electricity consumption. No significant effect on electricity consumption in Egypt were found the variables price and carbon emissions (Kwakwa, 2017).

\section{DETERMINANTS OF ELECTRICITY CONSUMPTION IN TURKEY}

\subsection{General}

Determinants for electricity consumption can be similar to the traditional theory of determinants which explains determinants for a commodity is determined mainly by price and income expressed mathematically as

$$
\operatorname{ELEC}_{t}=\alpha+\beta_{i} X_{t}
$$

- where ELECt is the quantity demand for electricity, at time $t$,

- $\mathrm{x}$ is a vector of explanatory variables (price and income) of ELEC and

- $\beta$ i represents the coefficient of each explanatory variable $i$.

Price usually has a negative relationship with energy consumption since a higher price will force consumers to reduce their level of consumption. On the other hand, because of the energy is taken as a normal good income tends to increase its consumption.

In this study, we follow three-step to find out the determinants of electricity consumption for the Turkish economy as unit root property of the series, cointegration test was applied to understand that whether there is a long-run relationship between variables and estimates of the long-term characteristics of electricity consumption in Turkey, using the Phillips and Hansen's (1990) Fully Modified OLS (FMOLS) models.

The stationarity of the series is tested using Augmented Dickey-Fuller (ADF) and the Phillips-Perron tests (PP). The use of parametric auto regression in the ADF test handles the serial correlation and heteroskedasticity problems in the residuals which is the reason it is a test widely used, while the Phillips-Perron (PP) test deals better with general forms of heteroskedasticity in the error term. The null hypothesis of the ADF and the PP test for stationarity is declared as the series not being stationary or containing a unit root and alternatively the series is stationary or does not contain unit root.

\subsection{Data sources and description}

This article uses data to examine the effects of income, industrialization, financial development price, trade openness, carbon emissions and education as determinants of electricity consumption in Turkey between the years 1960 and 2016.

The choice of this period is based on the data availability. Much of the data was taken from the World Development Indicators (2017). Price and education data are taken from TURKSTAT. It is expected that the consumption of electricity energy ( $\mathrm{kWh}$ per person) and the income will be affected positively. The reason is that the purchase of electricity as a normal commodity, the increase of income will increase the electricity demand. The level of industrialization is measured as the share of industry in GDP. Energy is needed for industrial activity, and the increase in the level of industrialization is expected to increase electricity 
consumption. However, when industries use energy efficient technology use, this will reduce electricity consumption. It is estimated that measuring the urban population by the number of urban populations will increase the electricity consumption positively. The reason for this is that the city centres are characterized by the presence of heavy industries and offices, which are predominantly connected to electricity. The effect of trade openness cannot be determined primarily because trade can increase or decrease electricity consumption. Trade measured by three proxies as export as share of GDP, import as share of GDP, and import and export sum as a share of GDP. Education is measured as the number of tertiary school enrolments, which is expected to reduce the intensity of electricity use. The price is measured as a consumer price index and a negative relationship is expected between electricity consumption and price. Carbon emissions are measured as $\mathrm{CO} 2$ emissions per capita. Financial development with uncertain impact on electricity consumption. Money supply used as proxy for financial development and it was measured money supply as the share of GDP. In Turkey, structural change occurred in 1980. For this reason, step dummy variables were used after 1980.

\subsection{Empirical Results}

First, unit root tests are summarized, followed by cointegration analysis and their results. Using FMOLS long-term estimates of electricity consumption in Turkey were studied. The Augmented Dickey-Fuller (ADF) and the Phillips-Perron (PP) tests were used to test for unit root, the results of these tests are reported in Table 1 . The results show nearly all variables are non-stationary at level, the variables that are stationary are the level of electric consumption (LELEC) and level of education (LEDU). At first difference all variables except price (P) and urbanisation (URB) become stationary. The results of the test confirm in at least one test that all the variables at level with the exception of stationary variables are non-stationary. On the other hand, at the first difference the variables for income per capita, level of industrialisation, financial development, carbon emission, and trade openness become stationary. The stationarity of the variables will ensure the results of the estimations to not generate any spurious results. 
Table 1. Unit root test results

\begin{tabular}{|c|c|c|c|c|}
\hline Variable & ADF & $\mathbf{P P}$ & ADF & $\mathbf{P P}$ \\
\hline At levels & \multicolumn{2}{|c|}{ with Intercept } & \multicolumn{2}{|c|}{ with Trend and Intercept } \\
\hline LELEC & $-3.318835^{* *}$ & $-4.000894 * * *$ & $-3.318835^{* *}$ & -1.695347 \\
\hline LYPC & 0.209104 & 0.217802 & -2.219869 & -2.425131 \\
\hline LIND & -1.999491 & -2.028639 & -1.879838 & -1.879838 \\
\hline LFIND & -0.973571 & -0.537351 & $-3.669605^{* *}$ & $-3.605805^{* *}$ \\
\hline LEDU & $-2.991593 * *$ & $-2.695806^{*}$ & -2.896788 & -3.042861 \\
\hline LCE & -1.549879 & -1.609269 & $-3.422205^{*}$ & -2.808503 \\
\hline $\mathrm{P}$ & 1.213575 & 5.151415 & 0.486093 & 2.077223 \\
\hline LURB & -2.374948 & $-3.622671 * * *$ & -0.728860 & 0.000113 \\
\hline LIMP & -2.164545 & -2.166285 & -3.155728 & -3.155728 \\
\hline LEXP & -2.119848 & -2.117794 & -2.667269 & -3.014458 \\
\hline LTRAD & -2.172836 & -2.160333 & -2.808368 & -3.090174 \\
\hline \multicolumn{5}{|c|}{ At first difference } \\
\hline LELEC & - & - & - & $-6.653926 * * *$ \\
\hline LYPC & $7.351278 * * *$ & $-7.351284 * * *$ & $-7.286215^{* * *}$ & $-7.286279 * * *$ \\
\hline LIND & $-7.874661 * * *$ & $-7.874661 * * *$ & $-8.017305^{* * *}$ & $-8.126052 * * *$ \\
\hline LFIND & $-9.640680 * * *$ & $-13.64520 * * *$ & - & - \\
\hline LEDU & - & - & $-6.175837 * * *$ & $-6.168636 * * *$ \\
\hline LCE & $-7.368409 * * *$ & $-7.369646 * * *$ & - & $-7.458747 * * *$ \\
\hline $\mathrm{P}$ & -0.397223 & -0.343807 & -2.041722 & -2.124596 \\
\hline LURB & -1.766822 & - & -2.909600 & -2.350019 \\
\hline LIMP & $-7.397519 * * *$ & $-7.764544 * * *$ & $-7.301739 * * *$ & $-7.639540 * * *$ \\
\hline LEXP & $-8.129061 * * *$ & $-8.112536^{* * *}$ & $-7.985998 * * *$ & $-7.970328 * * *$ \\
\hline LTRAD & $-7.363324 * * *$ & $-7.445702 * * *$ & $-7.229044 * * *$ & $-7.299898 * * *$ \\
\hline \multicolumn{5}{|c|}{ At second difference } \\
\hline $\mathrm{P}$ & $-7.163303^{* * *}$ & $-7.174490 * * *$ & $-7.229512 * * *$ & $-7.423121 * * *$ \\
\hline LURB & $-4.861007 * * *$ & - & $-4.821372 * * *$ & $-4.871392 * * *$ \\
\hline
\end{tabular}

$*, * *$ and $* * *$ denote $1 \%, 5 \%$ and $10 \%$ level of significance, respectively.

\subsection{Cointegration test results}

Cointegration tests employed the data. The results for the Engle-Granger and the Phillips-Ouliaris are reported in Table 2. The alternate trade openness measurements, export, import and sum of export and import, are each tested separately for cointegration tests therefore three separate test results are reported. In at least one test, cointegration is confirmed as well, which would mean that a cointegration exist between electricity consumption, financial development, education, export/import/sum of export and import, urbanisation, industrialisation, income price and carbon emission. Cointegration between variables implies that a long-run relationship exists between electricity consumption and the selected variables in Turkey. For the Turkish economy the long-run electricity consumption determinants can be expressed as the financial development, education, export/import/sum of export and import, urbanisation, industrialisation, income price and carbon emission of Turkey. 
Table 2. Engle-Granger Cointegration Test Results

\begin{tabular}{|l|c|c|c|c|}
\hline \multirow{2}{*}{ VARIABLES } & \multicolumn{2}{|c|}{ TAU-STATISTIC } & \multicolumn{2}{c|}{ Z-STATISTIC } \\
\cline { 2 - 5 } & VALUE & PROBABILITY & VALUE & PROBABILITY \\
\hline $\begin{array}{l}\text { LELEC, LYPC, LIND, LFIND, LEDU, } \\
\text { LCE, P, LURB, LIMP, }\end{array}$ & $-5.746587^{*}$ & 0.0747 & $-42.10785^{*}$ & 0.0606 \\
\hline $\begin{array}{l}\text { LELEC, LYPC, LIND, LFIND, LEDU, } \\
\text { LCE, P, LURB, LEXP }\end{array}$ & -5.545844 & 0.1065 & $-40.23892^{*}$ & 0.0895 \\
\hline $\begin{array}{l}\text { LELEC, LYPC, LIND, LFIND, LEDU, } \\
\text { LCE, P, LURB, LTRAD }\end{array}$ & $-5.684107^{*}$ & 0.0836 & $-41.51673^{*}$ & 0.0688 \\
\hline
\end{tabular}

$*, * *$ and $* * *$ denote $1 \%, 5 \%$ and $10 \%$ level of significance, respectively.

In Table 3. the results of financial development, education, export/import/ sum of export and import, urbanisation, industrialisation, income price and carbon emission on electricity consumption in the long-run are presented. The results for both FMOLS and CCR estimations being similar asserts the robustness of the results. When taken together per capita income (LYPC), carbon emission (LCE), price (P) and urbanisation (LURB) are found to have significant effect on electricity consumption in Turkey. The finding of the study establishes that per capita income and carbon emission have positive impact while price and urbanisation have a negative impact on Turkish electricity consumption. On the other hand, level of industrialisation (LIND), financial development (LFIND), level of education (LEDU), and trade openness (LIMP, LEXP, LTRAD) have seen to have no significant effect on electricity consumption in Turkey. The per capita income, carbon emission, and price coefficients are detected to have a significance level of 10 percent while the urbanisation coefficient has seen to have a level of significance at 1 percent.

Along with the interpretations above, income has been found to be a positive influence on electricity consumption in the Turkish economy. The income having a positive effect on electricity consumption has been confirmed in studies such as Adom and Bekoe (2013), Ekpo et al. (2011), Inglesi (2010), Rafindadi and Ozturk (2016) although the income coefficient was inelastic in their studies. Urbanisation is confirmed to employ a negative effect on the consumption of electricity in Turkey at a significance level of 1 percent.

Table 3. FMOLS Regression results: Dependant Variable LELEC

\begin{tabular}{|c|c|c|c|c|c|c|}
\hline Variables & Coefficient & Standard errors & Coefficient & $\begin{array}{c}\text { Standard } \\
\text { errors }\end{array}$ & Coefficient & $\begin{array}{c}\text { Standard } \\
\text { errors }\end{array}$ \\
\hline LYPC & $0.2858 * * *$ & 0.0727 & $0.2969 * * *$ & 0.0769 & $0.2835 * * *$ & 0.0730 \\
\hline LIND & 0.0103 & 0.0487 & 0.0188 & 0.0472 & 0.0208 & 0.0472 \\
\hline LFIND & 0.0011 & 0.0238 & -0.0032 & 0.0251 & -0.0004 & 0.0242 \\
\hline LEDU & 0.0367 & 0.0465 & 0.0514 & 0.0467 & 0.0439 & 0.0462 \\
\hline LCE & $0.3625^{* * *}$ & 0.0432 & $0.3617 * * *$ & 0.0446 & $0.3597 * * *$ & 0.0434 \\
\hline $\mathrm{P}$ & $-0.0028 * * *$ & 0.0007 & $-0.0027 * * *$ & 0.0008 & $-0.0027 * * *$ & 0.0007 \\
\hline LURB & $-0.4699 *$ & 0.2520 & $-0.5182 * *$ & 0.2639 & $-0.4960 * *$ & 0.2556 \\
\hline LIMP & $-0.0084-$ & $0.0147-$ & - & - & - & - \\
\hline LEXP & - & - & 0.0116 & 0.0144 & - & 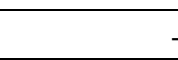 \\
\hline LTRAD & - & - & - & - & 0.0009 & 0.0161 \\
\hline Constant & $0.0765 * * *$ & 0.0104 & $0.0776 * * *$ & 0.0109 & 0.0771 & 0.0105 \\
\hline R-squared & \multicolumn{2}{|c|}{0.748167} & \multicolumn{2}{|c|}{0.749708} & \multicolumn{2}{|c|}{ 0.746941 } \\
\hline
\end{tabular}

$*, * *$ and $* * *$ denote $1 \%, 5 \%$ and $10 \%$ level of significance, respectively

$1 \%, 5 \%$ and $10 \%$ level of significance, respectively 
In the estimations, a positive relationship between electricity consumption is found with the variables LYPC and LCE and a negative relationship is found with the variables $\mathrm{P}$ and LURB. The LIND, LFIND, LEDU, and Trade (EXP, IMP) variables are found to have no significant effect on electricity consumption in Turkey.

The income per capita (LYPC) finding of a positive relation with electricity consumption is consistent with the literature. The usage of electrical devices is expected to increase as the welfare level elevates with the increase of income.

Carbon emission (LCE) and electricity consumption in Turkey having a positive relationship shows that electricity consumers in Turkey have low sensitivity to the environment. The energy usage is reduced when citizens become more concerned about the environment.

The relationshis between electricity prices and electricity consumption are expected to have a negative due to energy being taken as a normal good. Therefore, consumers will be forced to reduce their level of electricity consumption faced with higher prices.

The negative relation between urbanisation and electricity consumption tells us that electricity consumption in cities decreases as urbanization increases. While the urban population may be consuming more electricity, it is indicated that energy-saving electrical devices may be often used.

Industrialization (LIND) and electricity consumption have been found to have no statistically significant relationship. In the literature however both there are results that found positive relationships as well as those that found negative relationships. Industrialisation has been established to have a negative effect on the total energy consumption according to the study made by Keho (2016). The relationship between industrialization and electricity consumption being insignificant can be considered a sign that the industry in Turkey is connected to other energy sources than electricity.

The financial development variable (LFIND) was measured by the change in the money supply. No significant relationship between financial development and electricity consumption has been found. The literature shows different results, a positive relationship between electricity consumption and financial development is expected. Since financial development affects economic growth the effect of financial development on energy consumption is not direct. Economic growth has a positive effect on electricity consumption. If the economy prioritizes energy savings this effect may not be seen and in Turkey, this effect is not seen between 1960 and 2016.

The level of education (LEDU) seems to have an ineffective impact on electricity consumption in the estimation that was made.

Trade (EXP, IMP) for any of trade openness proxies have concluded to have no significant relationship between electricity consumption in Turkey.

\section{CONCLUSION}

Electricity is a form of energy that comes from the existence of charged particles. The flow of these charged particles in a period of time can be defined as electrical current. The electrical power a source generates is measured by the current times the electrical potential which is amount of this electrical work of a particle. Power plants that generates electrical power use various energy sources, the main sources used to produce electricity are fossil fuels, natural gases and hydro energy. Electricity generated from non-renewables sources such as coal or natural gases can be dangerous for the environment while electricity generated from renewable sources such as solar or hydro energy are less harmful to the environment. Electricity has a wide spread usage as it is the dominant energy source for most manufacturing in 
industries, households' electrical devices, and transport. The fact that electricity is a source that cannot be stored, the generation and transmission of it must be carefully calculated. This is done by the right modelling of electricity consumption.

The first generation of electricity in Turkey was in 1902 by a water mill producing $2 \mathrm{kV}$ of energy. The electricity generated in Turkey in 2016 was 167.3 billion kWh which show how much the electric sector has grown. Turkey's energy sources for generating electricity is mainly natural gas, followed by coal, hydraulic power, wind, geothermal energy.

The electricity consumption determinants of Turkey were analysed for the past 50 years (1960 to 2016) to assist the policies of electricity consumption management in Turkey. The results showed income, price, carbon emission and urbanisation had a significant impact on determining the electricity consumption. Fully Modified OLS (FMOLS) are used to estimate the determinants.

We found that price due to electricity being a normal good has a negative relationship which is an expected result. Another expected result is income having a positive and significant relationship with electricity consumption, again being considered a normal good the increase in income is expected to increase the amount of consumed electricity. In most studies done for both Turkey and for many other countries energy and consequently electricity has been taken as a normal good and has shown results indicating electricity consumption increases from increased wealth and decreases from raising price level.

Urbanisation has a negative relationship which was not an expected result due to the fact most of the reviewed literature showed a positive relationship between electricity consumption and urbanisation. Similarly, carbon emission having a significant impact on electricity is also a finding which is interesting and was not seen in most of the literature done. The negative relationship of urbanization with electricity implies energy saving devices are preferred. Whereas carbon emission is having a positive relationship is concerning due to the increasing electricity consumption's impact on the environment. The positive relationship indicates consumers are less concerned of the environment. 


\section{REFERENCES}

ALAWIN, M., AL-HAMDI, M., AND ALOMERI, M. (2016). Determinants of electricity demand in Jordan. Indian Journal of Science and Technology, 9(15).

AL-FARIS, ABDUL RAZAK F (2002). The demand for electricity in the GCC countries. Energy Policy, 30(2), 117-124.

BEDIR, M., HASSELAAR, E., AND ITARD, L. (2013). Determinants of electricity consumption in Dutch dwellings. Energy and Buildings, 58, 194-207.

DEMIREL. (2016). Energy: Production, Conversion, Storage, Conservation, and Coupling, Springer-Verlag London Limited

ENGLE, R. F., \& GRANGER, C. W. (1987). Co-integration and error correction: representation, estimation, and testing. Econometrica: journal of the Econometric Society, 251-276.Engle-Granger

EKPO, U. N., CHUKU, C. A., AND EFFIONG, E. L. (2011). The dynamics of electricity demand and consumption in Nigeria: application of the bounds testing approach. Current Research Journal of Economic Theory, 3(2), 43-52.

FAKIH, A. AND MARROUCH, W. (2015) The electricity consumption, employment and growth nexus: evidence from Lebanon. OPEC Energy Review, 39: 298-321. doi:10.1111/opec.12053

HUANG, W. H. (2015). The Determinants of Household Electricity Consumption İn Taiwan: Evidence from Quantile Regression. Energy, 87, 120-133.

KARAKIŞ, ESRA, (2017), “Aylık Enerji İstatistikleri Raporu”, Enerji ve Tabii Kaynaklar Bakanlığ 1 , Enerji İstatistikleri Daire Başkanlığ

KRISHNAMURTHY, C. K., AND KRISTRÖM, B. (2013). Energy demand and income elasticity: a cross-country analysis. CERE Working paper 2013:5 Umea University Sweden

KWAKWA, P. A. (2017). Electricity consumption in Egypt: a long-run analysis of its determinants. OPEC Energy Review, 41(1), 3-22.

MOHAMED, Z., AND BODGER, P. (2005). Forecasting electricity consumption in New Zealand using economic and demographic variables. Energy, 30(10), 1833-1843.

NASR, G. E., BADR, E. A., AND DIBEH, G. (2000). Econometric modelling of electricity consumption in post-war Lebanon. Energy Economics, 22(6), 627-640.

ÖZDEMIR, N. (2012). Türkiye'de Elektriğin Tarihsel Gelişimi (1900 - 1938). Ankara: Elektrik Mühendisleri OdasiPhillips, P.C.B. and Hansen, B.E., (1990) Statistical inference in instrumental variables regression with I(1) processes. Review of Economic Studies 57, 99-125

PHILLIPS, P. C., \& PERRON, P. (1988). Testing for a unit root in time series regression. Biometrika, 75(2), 335-346.

TAYLOR, L. D. (1975). The demand for electricity: a survey. The Bell Journal of Economics, 74-110.

TURKSTAT. (2017) Main Statistics, http://www.turkstat.gov.tr/ 
WORLD BANK. (2017) World Development Indicators 2017. Washington, DC. C World Bank. https://openknowledge.worldbank.org/handle/10986/26447 License: CC BY 3.0 IGO."

WORLD BANK. (2017) World Development Indicators 2017. Washington, DC. C World Bank. https://openknowledge.worldbank.org/handle/10986/26447 License: CC BY 3.0 IGO."

XIA, X. H., AND HU, Y. (2012). Determinants of electricity consumption intensity in China: analysis of cities at sub province and prefecture levels in 2009. The Scientific World Journal.

YAVUZ, H., GÜRKAN, F. AND ŞIMŞEK, S. (2017) Enerji Sektörünün Osmanlı ve Türkiye Cumhuriyeti Tarihindeki Gelişimi ve Yasal Süreç, www.enver.org.tr/UserFiles/Article/5e907eb0-43e2-44cf-ba0b-811db7b7b2d2.pdf (access date: 19.12.20 17) 
SEZGIN \& YILDIRIM / The Demand for Electricity Consumption in Turkey 